\title{
Is Another Language Possible?
}

\section{Citation}

Najmabadi, Afsaneh. Forthcoming. Is another language possible? History of the Present 2(2).

\section{Permanent link}

http://nrs.harvard.edu/urn-3:HUL.InstRepos:8338821

\section{Terms of Use}

This article was downloaded from Harvard University's DASH repository, and is made available under the terms and conditions applicable to Open Access Policy Articles, as set forth at http:// nrs.harvard.edu/urn-3:HUL.InstRepos:dash.current.terms-of-use\#OAP

\section{Share Your Story}

The Harvard community has made this article openly available.

Please share how this access benefits you. Submit a story.

Accessibility 
Afsaneh Najmabadi

Is Another Language Possible? ${ }^{1}$

Over the past decade, issues of gender and sexual rights (at times ensconced within human rights) in Muslim-majority countries have acquired urgent political circulations. Concurrently, critical positions regarding the deployment of this discourse of rights for imperialist ends have been articulated by many. I do not propose to add to this critique here. ${ }^{2}$ Instead, I would like to approach these debates with a different concern and pursue two related questions. If the language of rights has been appropriated by neo-liberal conservatives and folded into imperialist designs, as claimed by critics, what accounts for that possibility? And even more urgently, is another language possible?

Mid-decade, between the debates set off over "the plight of women in Afghanistan" in 2001 and the concerns over gays in the unfolding events of 2011 that acquired the title "Arab Spring," another episode provided the text of much heated debate. On July $19^{\text {th }}$, 2005, two young men, Mahmud Askari (16 years old) and Ayaz Marhuni (18 years old), were hanged in public, on rape charges, in the city of Mashhad, Iran. On that day the Iranian Students News Agency's website carried a brief report and three photographs, one of which immediately circulated worldwide and became an icon of what has become an international campaign for gay rights in Iran and a battle flag against Iranian government's execution of homosexuals.

Almost as immediately, the international campaign and the coverage of the case sparked critical debates within the human rights transnational activist communities, including over the legal complexities and the conflicting claims of factual details of the case. In a

\footnotetext{
${ }^{1}$ This essay is based on a talk presented at the Berkshire Conference, June 2011. I would like to thank Anjali Arondekar for inviting me to the panel she organized and for her critical comments on my presentation piece.

${ }^{2}$ See, for example, Lila Abu-Lughod, "Do Muslim Women Really Need Saving? Anthropological Reflections on Cultural Relativism and its Others," American Anthropologist, 104: 3 (September 2002): 783-790. For a most recent critique in the context of last year's developments in Middle East and North Africa, see Maya Mikdashi and R.M., "Gays, Islamists, and The Arab Spring: What Would A Revolutionary Do?”, al-Jadaliyya, June 11, 2011. http://www.jadaliyya.com/pages/index/1836/gaysislamists-and-the-arab-spring what-would-a-re
} 
talk at Harvard Law School in March 2008, Scott Long (at the time Program Director of Lesbian, Gay, Bisexual \& Transgender Rights Division of Human Rights Watch) reviewed the case, going over how this execution was initially reported, how this and several other subsequent cases over the previous three years had been subsumed in international campaigns under "gay prosecutions in Iran," and what problematic effects such subsumption had produced. ${ }^{3}$ After Long's presentation, an audience member, speaking as a gay rights and international human rights activist, resisted Long's objection to the subsumption of those executed under the label "gay." He asked [I am paraphrasing from notes]: "But how could someone like me become passionate about these cases and become active on the issue if I did not name them gay?"

The sentiment that informed this question was the familiar desire for "being the same" as the ground for work of solidarity. I say familiar because this was indeed a central desire in second-wave feminism, both informing its campaigns in the US and its relation to the struggles of women's rights activists globally as expressed in two of its most famous slogans: Sisterhood is Powerful and Sisterhood is Global. I emphasize both in the US and on the transnational scene, because I do not think this, like many other issues that we habitually categorize thus, is a West/non-West divide.

Since the 1970s, the power of, but more importantly the problems associated with, this desire have been at great length discussed in critical feminist debates. In particular, Janet Jakobsen incisively analyzed the effects of what she aptly called an "economy of the same" on the constitution of politics of singularity within feminist movements in the 1970s through the 1990s in the United States. ${ }^{4}$ Similarly, Denise Riley has critiqued the invocation of identification as grounds for solidarity, "For solidarity can veer between progressive warmth, pious constraint, narrowly tactical calculation, imaginative generosity, and unwarranted familiarity."

\footnotetext{
${ }^{3}$ For a published version, see Scott Long, "Unbearable witness: how Western activists (mis)recognize sexuality in Iran,” Contemporary Politics 15, 1 (March 2009): 119-136.

${ }^{4}$ Janet Jakobsen, Working alliances and the politics of difference: diversity and feminist ethics, Bloomington: Indiana University Press, 1998.

${ }^{5}$ Denise Riley, The Words of Selves: Identification, Solidarity, Irony. Stanford: Stanford University Press, 2000, p. 9. My emphasis.
} 
that question, and in how international campaigns on behalf of gender and sexual justice insist on naming the people with whom they desire to solidarize, works within the terms of the economy of the same and fails to reflect over what effects its familiarization of those young men in Mashhad by naming them gay produce.

While the working of this economy of the same enables international gay rights activists to name some people in Iran (and elsewhere) as gay and work in defense of their rights, this sameness is embedded within a progress narrative that imagines "their situation back in Iran" as a time past of gays here. This temporalization anticipates that the future of "gays in Iran" will and ought to look like "our present," that is, their situation will improve, as they will acquire rights in a more or less similar trajectory of political and cultural emergences. It produces the difference between them and us as a catching up operation that deserves international attention and solidarity, and grounds the moral imperative to come to the aid of our less fortunate gay brothers (sisters are occasionally included).

If these questions have been under critical scrutiny and analysis for more than two decades, how do we understand the persistent desire to do transnational solidarity work within an "economy of the same"? Furthermore, what accounts for the continued weight of the West/non-West divide and of the competitive comparativist urge across that divide -- whether we are asking questions about genealogies, histories, or about the politics of the struggles and possibilities of solidarities -- to the shaping of our dialogue today? ${ }^{6}$

I suspect there is no single or simple answer to this question. I will pursue one line of speculation here: that the long enduring life of the desire for the same, for familiarity even if unwarranted, is linked with another concept with equally (and related) long life. While there are important distinctions between the feminist desire and that of gay rights activists, both reference that troubling concept - identity - that emerged out of the

\footnotetext{
${ }^{6}$ I take the concept of 'competitive comparativitism' from Brad Epps, "Comparison, Competition, and Cross-Dressing: Cross-Cultural Analysis in a Contested World,” pp. 114-160, in Kathryn Babayan and Afsaneh Najmabadi, eds. Islamicate Sexualities: Translations across Temporal Geographies of Desire, Cambridge: Harvard University Press, Middle Eastern Monographs, 2008.
} 
contingent political campaigns of the past three decades in parts of North America and Europe.

As many scholars and activists have already observed and critiqued, much of the cultural weight and political heat around identities in the US has had to do with the investment in the very concept of identity. As Riley puts it, "the offer of contemporary identities is more straightforward: self-construction, to achieve a self. In this respect, identity politics lies closer to a sacrificial religion than to a civic ethics." (55) While we have contested, pluralized, fractured, destabilized, localized, and globalized identity; while we have turned it into a playful and performative concept, queered it and critiqued it, these multiplications and critical challenges have largely remained scripted within the paradigm of a self with a deep interiorized psyche as the central, as if inherent, quality of humanness. The historical contingency of this concept of self, and "the historicity as well as the arbitrariness of the categorical words that consolidate me," (Riley, 3) have remained less scrutinized. ${ }^{7}$

Let me pursue these questions of identification, naming, and concepts of self through a detour - my research on transsexuality in Iran over the period 2005-08 - before returning to the discussion of transnational solidarity on sexual rights. ${ }^{8}$

From the outset, my research faced enormous challenges of translation. I started with what seemed to be two simple, coherent, research questions: First, in a cultural-legal context where same-sex desire was considered shameful and same-sex practices were illegal, but within which transsexuality, even if largely received as socially shameful, was nevertheless legal and state-subsidized, how did this configuration shape sexual and gender subjectivities? Second, how did insistent state regulations and religio-cultural codes and rituals concerning proper gender conduct shape sexual desires and gender subjectivities? Both questions were in

\footnotetext{
${ }^{7}$ For two historically grounded and persuasive account of the emergence of this concept of self, see Dror Wahrman, The Making of the Modern Self: Identity and Culture in Eighteenth-Century England. New Haven: Yale University Press, 2004 and Jan Goldstein, The Post-Revolutionary Self: Politics and Psyche in France, 1750-1850. Cambridge: Harvard University Press, 2005.

${ }^{8}$ Sex-in-Change: Configurations of Gender and Sexuality in Contemporary Iran, Durham: Duke University Press, forthcoming.
} 
important ways informed by the conceptual distinctions between gender, sex and sexuality that had shaped my thinking over previous three decades of teaching, research, and activism in the United States. Very quickly, it became clear that many of the stories I heard, and lives I became part of, seemed incoherent, if not incomprehensible, were I to make them responsible for answering these questions.

The categorical distinctions shaping my questions were even more situated and contingent than I had anticipated. When it came to issues of sexual/gender identification, desire, and practices in Iran, a single concept -- linguistically and culturally [jins] - kept them together. Not only had no conceptual distinction between sexuality and gender emerged, but more significantly, lives were possible through that very non-distinction. ${ }^{9}$ The tight conjunction among sex/gender/sexuality has both enabled the work of changing the body to align its gender/sexuality with its sex and has set the parameters within which these changes are imagined and enacted. It has therefore necessarily contributed to a specific structure of selfcognition and narrative presentation among trans persons. The persistent pattern, for instance, of a tight transition from a cross-gender-identified childhood to an adolescence marked by sexual desire for one's own peers (yet another word for which jins stands) speaks to the indistinction between gender/sex/sexuality. This indistinction regularly disrupts attempts - by the state, religious leaders, medical professionals, and trans persons themselves -- to separate the homosexual from the trans.

As importantly, some of the conceptual distinctions between gender, sex, and sexuality within the Anglo-American context, including the distinction sometimes made between transgender and transsexual (based on surgical modifications to the body), have been shaped over the past decades by the identity politics of gender and sexuality, as well as queer

\footnotetext{
${ }^{9}$ This is not a cultural relativist proposition. The contingency of these distinctions is pertinent in other places as well -- as persuasively argued, for instance, by David Valentine in his ethnography of several sex/gender variant communities in NYC, Imagining Transgender: An Ethnography of a Category. Durham: Duke University Press, 2007. Moreover, in Iran, over the past three decades, in another domain - feminist activism - the distinction between sex/sexuality [jins] and gender [jinsiyat] has been carved out as a politically enabling parsing. In other words, in this domain there is an in-distinction between sex and sexuality but a parsing of gender - a conceptual move productive for feminist attempts to rid of the oversignified woman's body as a site of sex and sexuality by dismissing the significance of jins to meanings of gender (purifying gender of sex/sexuality) that is open to change through social and legal reform.
} 
activism and queer critical theory. Transsexuality in Iran has not been shaped by such developments. Given the different political and socio-cultural contexts, to what extent are analytical categories and theoretical distinctions developed in this recent Anglo-American context useful for understanding Iran? As Brad Epps noted, "Gender trouble, in a global frame, needs to be at once supplemented (in the deconstructive sense) and recast as 'translation trouble' or, better yet, 'language trouble.",10

A related question was: How did seemingly similar assignations mean differently (or not) within a different politics of sex, sexuality, and gender? How does one learn to hear resonances of familiarity, and understand their grammar in a different location and moment of utterance? What happens when words leave one setting and become enfolded into another? ${ }^{11}$ For instance, when $g a y^{12}$ first appeared in Iran of the 1970 s, it was largely avoided by local men who could so self-identify, because it was received as the English translation of a Persian word [kuni] with a highly pejorative and dishonorable load. Some twenty years later, it began to be embraced in part for an opposite effect: to distance oneself from that Persian pejorative assignation and to connect oneself to an imagined global community. As importantly, by the late 1990s, the designation gay had also become a delineating category separating one from transsexual, which had begun to acquire its own distinct recognition. Gay in today's Iran marks itself as dis-identification from kuni and from trans, its disavowed past and present.

Somewhat differently, for two young Iranian women I worked with, the accidental arrival of a self-identified Iranian-American lesbian into their lives allowed them to disavow and resist the locally available designations. For one woman, same-sex-player [hamjinsbaz] was

\footnotetext{
${ }^{10}$ Brad Epps, unpublished discussant's comments on draft of chapter 4 of my book, presented at the Harvard Humanities Center, Gender and Sexuality Seminar, September $30^{\text {th }}, 2009$. For related discussion of issues of travel of concepts and related linguistic-cultural transformations, see Mieke Bal, Travelling Concepts in the Humanities: A Rough Guide, Toronto: University of Toronto Press, 2002.

${ }^{11}$ On this issue see Anna Tsing's introduction in Carol Gluck and Anna Lowenhaupt Tsing, eds. Words in Motion: Toward a Global Lexicon, Durham: Duke University Press, 2009, pp. 11-17. Tsing's contribution in this volume, "Adat/Indigenous: Indigeneity in Motion," pp. 40-64, offers a dynamic understanding of the relationship between global categories and local cultures, "a model of difference in interconnection. ... Concepts in translation," as she argues, "both refer to something in common and exceed that common reference." (p. 41)

${ }^{12}$ I use the convention of italicizing words that have recently entered into Persian usage when pronounced the same as in English.
} 
pejorative and morally loathed; the other currently available identification, transsexual, did not feel quite right and seemed to be a fad to be resisted. Lesbian allowed her a distinct and satisfying self-cognition. Her partner became lesbian because of her location in relation to her. What work "the import" does in its local context, in relation to the many other concepts and practices that it becomes intertwined with and that inform its meaning in the transplanted space cannot be presumed predictable. As Brad Epps put it, "what is at stake if we ... query not simply agency in language but also agency in a particular language, a specific language, ... or, indeed, and importantly, between and betwixt specific languages, the very position, so to speak, of any number of subjects, trans or not ... who find themselves pulled, often quite painfully but also quite pleasurably, between two or more languages. What, in other words, occurs when two or more languages are understood, both in accordance to the general claims about language, as sites of agency? And what occurs, moreover, when such double (or triple, or multiple) sites, such double (or triple, or multiple) agencies are in conflict?"13

To say that gay, trans, lesbian, etc. do not mean the same thing everywhere and at all times is far from a novel proposition. ${ }^{14}$ But if we recognize that these enunciations may mean differently, and perform a different cultural work, in Tehran compared to New York, then we need to ask how that difference may affect a different politics of transnational solidarity. What are the implications of recognizing these differentiallysituated meanings of words for building alliances internationally on issues of sexual rights?

Relatedly, I suggest that the different stories about one's sense of being in the world - the specific cultural scripts for/of the self -- also matter in terms of what shapes local activism,

\footnotetext{
${ }^{13}$ Brad Epps, unpublished discussant's comments, previously cited. To clarify: I am not suggesting that no one in the "non-West" names him or herself gay or lesbian, but that one of the problems with the current heated debates between proponents of "global gay" and opponents of "gay international" resides in their common presumption that "I am gay" means the same thing anywhere it is pronounced. One may object that the same point could be made about other identifying categories, such as heterosexual, man, woman, etc. I agree. Similar historical sensibilities and ethnographic insights need to be, and have more often been, extended to these categories as well. Without such care, not only do we produce "bad history" and "flat ethnography," our political practices become oblivious to their own potentially adverse effects.

${ }^{14}$ See, for example, Mark Johnson, Beauty and Power: Transgendering and Cultural Transformation in the Southern Philippines. Oxford: Berg, 1997; Lisa Rofel, Desiring China: Experiments in Neoliberalism, Sexuality, and Public Culture. Durham: Duke University Press, 2007; Tom Boellstorff, A Coincidence of Desires: Anthropology, Queer Studies, Indonesia. Durham: Duke University Press, 2007.
} 
and that we need to be as attentive to these differences in our politics of transnational solidarity. The notion of a right-bearing individual, and the individual's "inalienable rights," that has been the foundation of rights-based activism is intimately linked to the narrative of an interiorized deep self. If we do not presume the universality of that individual and of the usability of the rights language, what shape could transnational activism take?

To begin with, we need to suspend some recurrent presumptions. Perhaps a key corollary to the previous two points would be to accept that if a language of rights is not the dominant, perhaps not even an emergent, language of activism, that need not indicate the severity of state repression, or the depth of cultural conservatism, that could be rectified by powerful international solidarity and activism. Once we suspend the expectation that languages that have worked for activism at a given time and place, e.g. human rights, are necessarily useful and usable languages for all times and places, then we need to learn what some of the languages and styles of activism that have emerged locally are before we could ask how could we, working with and through our differing languages and styles of practice, connect with the local emergences?

Local languages and styles are complex and continuously shifting, much the same way "there" as "here" - which also means that the point is not to authenticate and fix some at the expense of others. To give an example from the local scene of trans-activism in Tehran, the dominant pattern has not been one of translation of demands for addressing needs into a language of rights. Unlike the language of rights - human rights, sexual rights, etc. - discourse of need satisfaction does not seem to be a self-evidently universal discourse with a common vocabulary and grammar. One would have to necessarily be in conversation with local communities of activists and consider their perception and style of activism, before imagining the possibilities of transnational solidarity work. As far as trans-activism in Tehran is concerned, for instance, given the parameters of the religiolegal acceptability of transsexuality, lobbying for needs in terms of social entitlements, rather than demanding rights, has shaped trans-activism. ${ }^{15}$ Activists tended to work in the

\footnotetext{
${ }^{15}$ Only once, in a conversation with several trans persons in the waiting room of Mirdamad Clinic, did I hear one MtF say "we have rights like any other citizens. We should work for being recognized in the
} 
pattern of engaging in a "small and inconspicuous acquisition of entitlements." 16 That the same word in Persian is often used both for rights and entitlements [haqq] lends itself to productive ambiguities, overlaps, and possible future shifts from one meaning to another. But for the moment, trans-activism has taken shape in the pattern of "incremental and fragmented actions by numerous actors," similar to what Asef Bayat has analyzed as the "Logic of Practice in Nonmovements." 17 While unlike the "nonmovements" that Bayat analyzes, trans persons do not measure in "multi-millions," on a more numerically limited scale and localized level, that is nevertheless the pattern in which trans-activism has worked. Some of the actions bear a logic similar to those enacted by much larger groups - that is, in how repeatable and repeated actions by numerous individuals comes to produce the same effect as generalized policy. A well-known example in the domain of women's rights in recent years has been to force a reluctant husband to agree to a divorce by the wife going to court and demanding immediate payment of her mahr - the contractually binding gift (in money or goods) owed by husband to wife upon marriage. While women do not have easy access to demanding a divorce, they can ask for such payment at any time after marriage contract has been signed. The legal action brings the husband to court and often results in his granting the desired divorce instead of paying the mahr. This route has now become repeatedly and successfully used by many women, and has become widely known as "getting a divorce by asking for an enforcement of mahr payment" [mahriyah bah ijra guzashtan].

With a similar logic, trans persons have learned how to ask their physicians to write, in their letters of referral for various surgeries, hormonal, or laser treatments: "This is not an elective procedure; it is medically required." This simple phrase entitles the person the costs covered by insurance companies or by state hospitals, effectively as if it were a state-coded guidance for physicians. The success of this step has translated into the

Constitution," whereupon a lot of skeptical looks turned toward her, with several people saying that speaking of constitutional rights would get them no tangible results and would turn their needs into a political football.

${ }^{16}$ See Thomas Blom Hansen and Finn Stepputat, eds. States of Imagination: Ethnographic Explorations of the Postcolonial State. Durham: Duke University Press, 2001; the quote is from page 18 of the introduction.

${ }^{17}$ See Asef Bayat, Life as Politics: How Ordinary People Change the Middle East. Stanford: Stanford University Press, 2010; pp. 19-22. 
Welfare Organization publicly advocating the same. ${ }^{18}$ It is through a dynamic of working with and through governmental institutions that trans-activists have initiated, re-shaped, brought their own agenda into play, and simultaneously made themselves into subjects of governmental play.

Moreover, despite their regular engagement with structures of policy and governance, trans-activists frequently and insistently iterate a concern against the "politicization" of their issues. While insisting that they did not wish their cause to become politicized, trans-activists practice what many other activists would consider "political engagement" [ta 'amul-i siyasi] with the state -- an orientation much contested within women's rights activist communities. Not only do they go to various governmental offices on an almost daily basis to lobby for various needs, but they also go to the offices of the highest positions of governmental power - including the Office of the President and the Office of the Supreme Leader - to plead their case. The one major political institution with which they have not engaged is the Majlis [Iranian parliament]. Not going to the Majlis speaks to the shape of trans-self-formation as a body seeking entitlements not rights. The process of change through legislation is a volatile and prolonged one, arduous and often of dubious results. Moreover, the Majlis has historically been the location of engagements for claims of rights, rather than for the acquisition of entitlements. The women's movement, for instance, in its long, fractured, and contested history of politics of engagement with "the state," has often "gone to the Majlis" rather than to other governmental institutions. Its formation through a conception of rights and its primary focus on changing laws that discriminate against women have shaped its politics of engagement (or boycott of engagement) with the state through the legislative house of the Majlis. $^{19}$

\footnotetext{
${ }^{18}$ Hasan Musavi Chilik, Director General of the Office for the Socially Harmed, in his January 22, 2010 interview, explained, "A great many of TSs have no insurance coverage ... in addition many insurance plans do not accept their responsibility to pay the cost of this surgery, since they have put it under cosmetic surgery, whereas this ailment has nothing to do with beautification and cosmetic surgeries." FarsNews, January 22, 2010, http://www.farsnews.net/newstext.php?nn=8810290914.

${ }^{19}$ For this long and rich history, see Parvin Paidar, Women and the Political Process in Twentieth-Century Iran. Cambridge: Cambridge University Press, 1995; and, more recently, Arzoo Osanloo, The Politics of Women's Rights in Iran. Princeton: Princeton University Press, 2009.
} 
Unlike the broad shape of women's rights activism, formed around rights and shaped in terms of engagement with or opposition to institutional sites of state power, transactivism (with its need-centered pragmatics) has tended to think of state-focused politics - the fracturous ever-shifting political configurations of who is in charge of which political office - as detrimental to their cause. They have aimed to make sure that their access to such offices as the Welfare Organization, the Ministry of Health, and so on would not be affected by the political markings of the occupants of the office. Whether it is Khatami or Ahmadinijad in office, they need to be able to go to the Presidency. Whether it was Khomeini or now Khamenei, they need to go to the Supreme Leader. "Not political" means they want to keep their needs and entitlements guarded from the continuous vagaries of occupants of offices all the way down to ministries, judges, and lower-echelon bureaucrats. They need to be close enough to individuals to get things done, but not too closely identified with any individual.

This contrasting understanding of politics and different orientations vis-à-vis "engagement" is an effect of the legibility of transsexuality and the continued illegibility of the equality paradigm that feminists face within the dominant Islamic discourses differentially impacting their domains of possibility. Trans legibility has made a rightscentered discourse at best unnecessary and, worse, potentially risky, as it would open up transsexual issues to the political vagaries of "the state." While Islamic rulings (e.g., Khomeini's fatwa on permissibility of sexual surgeries) has been enabling for setting the parameters of social cognition and the satisfaction of needs, the Islamic rulings on women, family law, inheritance, exclusion from certain offices, and other numerous levels of discrimination have made the deployment of the rights indispensible for women's rights advocates. The Majlis is seen as the primary seat of laws/rights. As far as trans-activists are concerned, they have already received their badge of citizenship/social cognition in Khomeini's fatwa. Any other parliamentary grand document would pale in contrast. To the extent that regulations need legislation, their orientation from a local to a larger scale has paid off. After all, even if a law is passed, the implementation is back on the local level, where local alliances make it work or fail. 
"Not wishing to become politicized" has also impacted trans-activists' skepticism toward the discourse of rights. In addiction to their dismissal of the usefulness of engaging with the legislative, the rights discourse has become entangled within a volatile international scene with which they had engaged for publicity in 2003-04 but towards which they have grown distrustful. This was a scene over which they felt they had no control. While individual trans persons did try to use international engagement to expand their life options (including through asylum and immigration), as a collective body, the activists seemed to have grown increasingly wary of such entanglements.

The success of trans-activists' language and style of self-presentation has also impacted the conversation among self-identified gays and lesbians who, while living in contiguity with the trans communities, distinguish their needs and desires. Undoubtedly, some have sought strength through connections with Iranian diasporic gay and lesbian communities. Others have begun to look to their trans "neighbors," asking what they could learn from the latter's success. In particular, and in relation to the spread of HIV/AIDS and its association with male same-sex practices, they have begun to ask if a similar discourse of "vulnerability" ["vulnerable to social harm"] as invoked by trans-activists to lobby for needed services and entitlements, could also be used to expand the social and legal room for their communities. As Michael Fischer has noted, “'Vulnerable' is a key cultural term, a legal, moral, theological, psychiatric, psychological, hormonal, medical and surgical 'switching point.' It is a legal term and category that shifts the grounds of debate from internationally defined 'human rights' language to less contested, more local and contextual, languages of welfare, justice and vulnerability. It opens up bureaucratic space using psychiatry as a procedural means of regulation and defense. ${ }^{20}$

But given the complexities of a needs-satisfaction orientation, compared to our comfort with a rights language, how could we build any international solidarity? If the language of rights is not a usable one, what language could we imagine on the basis of needs and substantive entitlements, and not in terms of rights and legal protections? Is this not a prescription for

\footnotetext{
${ }^{20}$ Michael M. J. Fischer, "Philosophia and Anthropologia: Reading alongside Benjamin in Yazd, Derrida in Qum, Arendt in Tehran," unpublished manuscript; quote from page 21.
} 
inaction and paralysis in the face of persecutions and executions? Is another language indeed possible?

Let me try to respond to this concern by returning to the question addressed to Scott Long. The interrogator wanted to know "what harm did it do if we named them gay, even if they didn't call themselves so," if that naming enabled us to get passionate and actively campaign in their defense? The problem with that line of argument is that it begins with what may enable gays internationally to identify with a group of people in Iran, facing various forms of punishment. But naming them gay constituted them as a category that may indeed not help their situation in Iran. For instance, the two young men in July 2005 were not the only people who have been executed on charges of rape. What is called "violent rape" is a capital punishment and generally over the past five years there has been an alarming increase in executions on charges to do with crimes of rape and adultery, most of which concern heterosexual rape and consensual adult sexual relations. Strictly speaking, no one has been executed on charge of being gay or homosexuality. Being gay is not criminalized in Iran, nor is there a category named homosexuality in Islamic jurisprudence or law; homosexuality appears primarily in psychiatric medical texts and now increasingly in popular psychology advice books about sexual relations. What is a capital crime is sodomy between two men. ${ }^{21}$ Is the increasing slippage between sodomy and homosexuality, in part through transnational travel of these concepts, helpful to lives of gays in Iran? ${ }^{22}$

\footnotetext{
${ }^{21}$ In earlier versions of the penal code, currently under revision, punishment of sodomy appears under the same section as adultery [section titled "adultery and related matters (lavat, tafkhiz and musahiqah \{sodomy, intercrural sex, and tribadism\})"]. In a later version, adultery has been made into a separate chapter from the other three.

${ }^{22}$ As I write these lines, various versions of the penal code under parliamentary revision are becoming available. In an earlier version, after defining the punishment of various acts between two men and two women, what does not fit within those definitions falls under other acts of hamjinsbazi [same-sex playing] and said to be punishable by a maximum of 74 lashes (discretionary upon the judge's decision; articles 22124 and 221-29); in the penultimate version the word hamjinsbazi has been changed, in article 237, to hamjinsgara'i [same-sex orientation - an expression that hitherto was largely circulating in psychological discourse in Iran]. When psychiatric diagnostic language creeps into the law, this is surely not a positive development. My thanks to Alireza Doostdar for making a copy of this version of the Penal Code available to me.
} 
The two young men executed in 2005 were charged with anal rape of a younger male teenager, whose father had brought charges against the two older teenagers in that triangle. Indeed, over the previous months between the initial pronouncement of their death sentence and their execution, several lawyers, including Nobel laureate Shirin Ebadi, were campaigning to suspend their death sentences on the ground that they had been under-age when the purported crime had occurred. The advocacy of this position was articulated in terms of defining adolescence as a period of vulnerability, when youthful immaturity makes "children" easily impressionable and responsive to harmful influences. ${ }^{23}$ While their campaign was in the end not successful in this case, there has been a growing sentiment against considering persons in the 15-18-years-age category adult for purposes of capital punishment (15 is generally the age of adulthood in Iran, including voting age). This campaign has occasionally won cases. While the law had not yet changed, almost every under-age sentence was sent to the Chief Justice for review and he suspended some of them over the past several years. The campaign lost some momentum in the aftermath of June 2009 elections and the general crackdown against dissidents. A leading advocate, Mohammad Mostafaei, faced with various serious charges, was eventually forced to leave the country in summer 2010. Yet the approach had much wider impact than may have been suspected. The recently revised penal code, currently waiting its final presidential approval, has finally responded to this issue:

Article 141-1 of the new law defines "child as concerns this legislation as anyone who is under 18 solar years of age." 24

\footnotetext{
${ }^{23}$ For an elaboration of this argument, see Mohammad Mostafaei, "The Age for Capital Punishment and the Existing Laws," Etemad, April 11, 2008, p. http://www.etemaad.ir/Released/87-03-22/229.htm\#100500 ${ }^{24}$ The full text of an earlier version of the law is available at http://www.dadkhahi.net/law/Ghavanin/Ghavanin Jazaee/layehe gh mojazat eslami.htm. For he news of its final ratification by the Council of Guardians, see Shargh, February 12, 2012, p. 19, http://sharghnewspaper.ir/News/90/11/23/24421.html; for a related commentary, see Muhsin Rihami, "Responding to a Social Need," p. 1, Shargh, February 13, 2012, http://sharghnewspaper.ir/News/90/11/24/24515.html.
} 
By putting people like Mahmud and Ayaz in an identity category named gay, and separating their case from other cases of under-age persons on the death row, the international gay rights campaign would not have necessarily helped their defense. ${ }^{25}$

I do not suggest that the very divide between international gay rights advocates and their critics is a 'Western'-'native' divide. As I have already argued, since the 1990s there has been an increasing circulation of concepts such as gay, lesbian, trans, albeit with locally articulated meanings. Over the same decades, some of the first Iranian gay and lesbian diasporic circles have also become organized, and begun to build alliances with local and international gay and lesbian rights advocates and to campaign for gay and lesbian rights in Iran. The problem is that the privileging of directly challenging anti-sodomy laws and social restrictions by gay diasporic Iranian organizations (such as Homan in the 1990s and more recently by IRQO) tends to ignore that direct confrontation may not be the only - nor necessarily the most effective - way of creating social room for livable and loving lives in Iran. That singularly focused insistence tends to at best pity men, women, and trans persons who engage in inventive social practices in their daily lives as oppressed, as deprived of real choices or the correct consciousness. The flourishing of an international gay culture and of gay solidarity and human rights movement, and its promissory liberatory possibilities, make a new style of living gay lives as if a necessity, and living otherwise only a sign of internalized self-hatred and socio-legal oppression. The current internet gay discourse is saturated with such moralizing progressist narratives, defining its own homo-normalizing contours against the foil of these "past" and/or oppressive behavior.

\footnotetext{
${ }^{25}$ The other domain in which a growing movement for improvement of rights and decrease of punishments has been under way in Iran is to suspend all cases the sole basis for which is confessions obtained under duress, whether prosecutional pressure or fears of blackmail - usually the case with all consensual "sexual crimes." Because of very strong witness requirements for such infringements of the law, almost impossible to fulfill, the overwhelming evidence presented by prosecutors is confessions. Again, persons under the charge of sodomy are in the same situation, legally speaking, as those with charges of heterosexual adultery. These campaigns, I suggest, would be a lot more life saving than separating one group of adults and naming them gay - a move that Long has argued in some cases may have contributed to worsening their situation.
} 
At issue, then, is not to deny that the increasing self-referential circulation of terms such as gay, lesbian, etc. among Iranians today may indicate a different and emergent conceptual mapping of sexual practices and desires; what is problematical is the privileging of this emergent naming and configuring it as the same globally and as intrinsically superior to other modes of living non-hetero-normative sex/gender lives. 